\title{
Czechosłowacja w obliczu wrogiej postawy Niemiec i Włoch w 1938 roku
}

Zarys treści: Sytuacja Czechosłowacji w 1938 r. była bardzo zła. Osamotniona, starała się za wszelką cenę nie dopuścić do utraty swej suwerenności. Niemcy i Włochy, coraz bardziej pewne, że nikt nie ujmie się za Pragą, nie kryły się z wrogością wobec niej. Pamiętniki Josepha Goebbelsa i Galeazzo Ciano pozwalają prześledzić opinie na temat przyszłości państwa czechosłowackiego.

Outline of content: A situation of Czechoslovakia in 1938 was very bad. Standing alone, Czechoslovakia tried at all cost to retain its sovereignty. The Germans and Italians, however, more and more certain that no other country would stand up for Prague, were showing themselves increasingly hostile towards Czechoslovakia. The diaries of Joseph Goebbels and Galeazzo Ciano make it possible for us to follow opinions about the future of the Czechoslovak state.

Słowa kluczowe: Czechosłowacja 1938, Joseph Goebbels, Galeazzo Ciano, polityka zagraniczna Niemiec w okresie międzywojennym, polityka zagraniczna Włoch w okresie międzywojennym

Keywords: Czechoslovakia 1938, Joseph Goebbels, Galeazzo Ciano, Germany’s foreign policy in the interwar period, Italy's foreign policy in the interwar period

Zdeklarowanymi wrogami państwa czechosłowackiego był Niemcy Adolfa Hitlera i Włochy Benito Mussoliniego. Minister propagandy Trzeciej Rzeszy Joseph Goebbels nie krył swego negatywnego nastawienia do Czechosłowacji. Podobnie czynił włoski minister spraw zagranicznych Galeazzo Ciano. Dzienniki Goebbelsa i dzienniki Ciano rzucają interesujące światło na politykę zagraniczną Niemiec i Włoch.

Pod datą 14 stycznia 1938 r. Goebbels zauważył w swoim dzienniku, że „Czechy uprawiają szaleńczą politykę. Zasada: egoizm na dzisiaj. To przynosi najczęściej katastrofę jutro". O polskim ministrze spraw zagranicznych Józefie Becku Goebbels wypowiadał się życzliwie, pisząc, że „jest to mądra i rzeczowa głowa” oraz że „W sumie układ niemiecko-polski z 26 stycznia 1934 r. funkcjonuje”, natomiast 
„Rosja nie jest obecnie zdolna do zawierania sojuszy” ze względu na czystki przeprowadzane przez Stalina w Związku Sowieckim. Wyrażał też przekonanie, że Beck „chyba także jest lojalnym partnerem”. Pod adresem Czechosłowacji Goebbels używał inwektyw: „Czechy to prawdziwa kupa gówna” napisał w swoim dzienniku pod datą 29 stycznia $1938 \mathrm{r}^{1}$

Komentując mowę Hitlera w Reichstagu z 20 lutego 1938 r., Goebbels zwrócił uwagę, że „Niemczyzna w Czechosłowacji została wzięta pod opiekę Rzeszy. Rosja zaś uznana za odwiecznego wroga, z którym nie ma pojednania". Pod datą 1 marca 1938 r. Goebbels odnotowal, że „Stalin robi procesy pokazowe przeciwko Bucharinowi, Rykowowi, Jagodzie etc. Szalona tragikomedia, na którą może sobie pozwolić jedynie całkowicie przegniła i moralnie wykolejona Europa”. 21 marca 1938 r. niemiecki minister zauważył, że „Polska wyszła zwycięsko z konfliktu z Litwą”, która została „kompletnie pokonana” i bezzwłocznie nawiązuje stosunki dyplomatyczne z Polską. Goebbels nie omieszkał też zwrócić uwagę, że „Czesi okazują teraz powoli większą przychylność Niemcom sudeckim”. „Tylko że za wolno i jedynie ze względów taktycznych”. „To już im niewiele pomoże - wyrokował Goebbels, dodając, że - Czesi są zgubieni, wszystko zrobili za późno". Pod datą 24 marca 1938 r. zauważył, że „Belgia bardziej dystansuje się wobec Pragi” i „nikt nie chce mieć nic wspólnego z Czechami”. „Poza tym niemieckie ugrupowania odpryskowe opuszczają praski rząd i przechodzą do Henleina”. „Biedna Praga! Niewiele z tego pozostanie" - fałszywie współczuł Goebbels politykom czeskim.

W oczach Goebbelsa Beck zajął w stosunku do Litwy stanowisko umiarkowane. „To jest bez wątpienia realistyczny polityk” - ocenił niemiecki minister osobę polskiego ministra spraw zagranicznych. Polska protestuje w Pradze w związku z polityką kominternu - zauważył Goebbels w dzienniku pod datą 3 kwietnia 1938 r. i, oceniając zaistniałą sytuację, wskazywał, że „Praga wpakowała się w straszne kłopoty”. Rozmowy Konrada Henleina, przywódcy Niemców sudeckich, z premierem czechosłowackim Milanem Hodžą nie przyniosły żadnych efektów. „Henlein pertraktował z Hodżą, ale naturalnie bez rezultatu” - napisał w dzienniku 7 kwietnia 1938 r. niemiecki polityk. „Ci Czesi zupełnie nie wiedzą, co właściwie w trawie piszczy, biedni głupcy”, dodawał Goebbels z nutą wyższości. 14 kwietnia 1938 r. Henlein złożył raport Goebbelsowi: „Czesi pełni obaw. Mam kłopot, aby powściągnąć moich ludzi”.

Według Goebbelsa „opór Czechów na niewiele się zda, choć czeskie fortyfikacje są bardzo dobre. Prezydent Edvard Beneš obecnie bardzo zabiega o zgodę, ale jest za późno. Niemcy sudeccy chcą teraz jedynie powrotu do Rzeszy. Taktyka Henleina: żądać zawsze więcej aniżeli można dostać, zdała egzamin. Już my dojdziemy do celu. Czesi bardziej się boją, niż kochają ojczyznę" - uważał Goebbels. Pod datą 24 kwietnia 1938 r. postulował, aby „Czechów stopniowo zamęczać” oraz chwalił

\footnotetext{
1 J. Goebbels, Dzienniki, t. 1: 1923-1939, Warszawa 2013, s. 414-415, 418, 428; G. Ciano, Dziennik 1937-1943, Pułtusk 2006.
} 
Henleina, że ten „wykonał dobrze swoją robotę”. 28 kwietnia 1938 r. Goebbels zwracał uwage, że „Praga szuka oparcia w Paryżu i Londynie” oraz twierdził, że Beneš jest bliski przegrania swojej rozgrywki.

7 maja 1938 r. Goebbels odnotował w dzienniku, że w „sprawie czeskiej Mussolini daje nam [Niemcom] absolutnie wolną rękę". 30 maja 1938 r. Goebbels wyznał: „chcemy stopniowo usuwać Czechów z Niemiec, przede wszystkim z Wiednia. Nie powinni służyć w wojsku, aby nie prowadzili dalej roboty destrukcyjnej”. 1 czerwca 1938 r. Hitler scharakteryzował Czechów jako ludzi bezczelnych, zakłamanych, dewocyjnych i służalczych. Wtórował mu Goebbels, dodając, że Hitler ma jeszcze wiele zamiarów w stosunku do Czechów. Oni jeszcze ściągną na swoją głowę śmiertelne niebezpieczeństwo - prorokował Goebbels, który uważał jednocześnie, że Czechosłowacja „to zasrane państwo, które musi zniknąć. Im szybciej tym lepiej”. 17 czerwca 1938 r. Goebbels na audiencji u Hitlera przypomniał, że Beneš „jest naszym fanatycznym przeciwnikiem. Nie jest człowiekiem wielkiej miary. Inaczej prowokowałby od $1933 \mathrm{r}$. wojnę prewencyjną z nami albo szukałby porozumienia. Przynajmniej robiłby to teraz. Ale Bogu dzięki brakuje mu rozsądku i wielkości. I tak to Praga zmierza ku swojemu nieuniknionemu losowi”. Goebbels nie miał wątpliwości, że Hitler jest „całkowicie zdecydowany zabrać się przy pierwszej najlepszej okazji do sprawy Pragi. I to jest słuszne. W inny sposób nigdy nie dojdziemy do celu”. 6 lipca 1938 r. Goebbels rokował, że problem Pragi będzie niebawem rozwiązany. Podkreślał, że „z Polską musimy pozostać razem”. 25 lipca 1938 r. Goebbels zapowiadał, że „sprawa Niemców sudeckich musi być rozwiązana siłą”, gdyż „Praga nie chce okazać zrozumienia”. Według Goebbelsa Hitler „chce uniknąć wojny” i „dlatego przygotowuje się do niej za pomocą wszelkich środków”, a „nienawiść między Niemcami i Czechami jest nie do przezwyciężenia”. „Co ma się stać z 6 milionami Czechów, gdy kiedyś zajmiemy ich kraj? Trudny, prawie nierozwiązywalny problem”, żalił się Goebbels 1 sierpnia 1938 r. Podkreślał, że „Beneš jest naszym głównym wrogiem”, zaś „naród [czeski] jest obojętny i liczy na pomoc innych”. Hitler „rozmyśla jeszcze nad kwestią Pragi, ale w duchu ją już rozstrzygnął". 22 sierpnia 1938 r. Goebbels odnotował w swoim dzienniku, że nie wolno nam „narodów Europy [Środkowo-Wschodniej] przede wszystkich Czechów i podobnej hołoty rozpieszczać, raczej w pewnym momencie je przepędzimy. Nie chcemy tych narodów, chcemy ich krajów”. 12 września 1938 r. Henlein, charakteryzując Goebbelsowi czeski naród, stwierdził, że „dawać Czechom państwo to czysty absurd”. Sądził jednak, że Czesi będą do pewnego momentu zawzięcie walczyć, potem jednakże załamią się całkowicie. 15 września 1938 r., odnosząc się do stosunków z Polską, Goebbels okazał brak zaufania, oświadczając, że „nigdy nie można w pełni dowierzać polskiej przyjaźni”’2.

20 września 1938 r. Goebbels wyznał, że „podsłuchujemy rozmowy między Benešem a jego posłem w Londynie Janem Masarykiem”, Beneš „był i jest jednym

2 J. Goebbels, op. cit., s. 418, 428, 440, 441, 444, 447, 448-449, 450, 470, 473, 489, 491. 
z naszych najbardziej nikczemnych przeciwników: niebezpieczny, cwany, zakłamany i intrygancki”. 3 października 1938 r. wieczorem przywódcy Trzeciej Rzeszy spotkali się u Hitlera, który dokonał przeglądu sytuacji politycznej. Hitler „trwa niewzruszenie przy decyzji zniszczenia Czech przy pierwszej okazji. I on to zrealizuje. Ten martwy i amorficzny twór państwowy musi upaść” - relacjonował Goebbels. „A te Czechy któregoś dnia przecież połkniemy. Droga na Bałkany musi stanąć otworem” - dodawał. Hitler 10 października 1938 r. obejrzał czeskie bunkry i też przekonał się, że militarne pokonanie Czech kosztowałoby wiele krwi „tak jak jest, jest więc najlepiej, jak może być". Pod datą 22 listopada 1938 r. została zawarta informacja, że „granica z Pragą ustalona. Przeprowadzamy bezpośrednią autostradę z Wrocławia do Wiednia. Przez środek Czech. Niewiele więc zostanie z tego suwerennego państwa"3.

6 marca 1938 r. Ciano przyjął Becka w Rzymie. Przy okazji zauważył, że polski minister „nie wydaje mi się zbyt filoniemiecki”. Beck kilkakrotnie powtarzał, że w przypadku konfliktu wywołanego przez problem czeski sojusz z Francją nie zadziała. „Ostatecznie - stwierdził Ciano - określiliśmy odpowiednią formułę, ponieważ polityka naszych obu państw [Polski i Włoch] traktuje porozumienie z Niemcami jako czynnik zasadniczy. Znajdują się one [Polska i Włochy] w podobnym położeniu i mają pokrewne interesy, to znaczy z Jugosławią, Węgrami i Rumunią". Po wcieleniu Austrii do Rzeszy Niemieckiej Mussolini powiedział, że z mapy Europy usunięto niepewny punkt. Wymienił jeszcze trzy takie punkty, które - jego zdaniem - spotka ten sam los, a podał je w takiej kolejności: Czechosłowacja, Szwajcaria i Belgia. Ciano wyjaśnił też, że „odmówiliśmy wywierania presji na rząd w Warszawie [w kwestii kryzysu polsko-litewskiego] ponieważ z własnego doświadczenia wiemy jak nieznośne są tak zwane rządy-nauczyciele, czyli te, które zawsze czują potrzebę pouczania innych i mówienia im, że ich krok wywrze na kimś takie lub inne wrażenie". Według oceny jednego z brytyjskich polityków konserwatywnych Leopolda Amery'ego Czechosłowacja jest w desperackiej sytuacji. Amery twierdzi, że ,interwencja w tej sprawie przyniosłaby kiepskie rezultaty. To tak, jak rzucanie kamieniami w lwa, który pożera człowieka. Wprawdzie lwu się przeszkadza, ale człowieka to nie uratuje" - odnotował w dzienniku Ciano pod datą 14 kwietnia 1938 r.

Ribbentrop oświadczył włoskiemu ministrowi spraw zagranicznych, że „gdyby jednak rozgrywka [o Czechosłowację] musiała być rozstrzygnięta zbrojnie, to dokonałoby się to w ciągu kilku dni, szybciej niż ktokolwiek mógłby zareagować”. Ribbentrop stwierdził również, że Niemcy „chcą wzrostu sił Polski, bo to wzmocniłoby antybolszewicką barierę".

13 maja 1938 r. Mussolini oświadczył Ciano, że „Francuzi to naród zrujnowany przez alkohol, syfilis i dziennikarstwo”. Ciano natomiast powiedział posłowi Czechosłowacji w Pradze Františkowi Chvalkovskiemu, że „życzymy sobie pokojo-

\footnotetext{
3 Ibidem, s. 507, 508-511.
} 
wego rozwiązania kwestii czeskiej, ale nie jesteśmy nią zainteresowani bezpośrednio i dlatego w tej sprawie możemy zająć jedynie postawę neutralną. Nie drgnęliśmy w sprawie Austrii, jakże więc mielibyśmy działać na rzecz Pragi?”. 21 maja 1938 r. Ciano zreferował Mussoliniemu sytuację w Czechosłowacji. Duce potwierdził, że nie interesują go losy tego kraju. Nie wierzył, żeby Francja zmobilizowała się do jego obrony. Ciano „potwierdził włoską neutralność w kwestii czeskiej”. Mussolini „uważa, że sprawa czeska nie jest tak groźna jak wielu utrzymuje” zanotował w swoim dzienniku Ciano pod datą 22 maja 1938 r. 26 maja 1938 r. Ciano oświadczył ambasadorowi niemieckiemu Hansowi Mackensenowi, że włoski punkt widzenia na kwestię czeską nie różni się od niemieckiego. „Nie jesteśmy zainteresowani losami Pragi, a zarazem w pełni solidaryzujemy się z Niemcami" - oświadczył włoski minister spraw zagranicznych. Ciano odnotował, iż „mimo że nie wydarzyło się nic nowego, Duce był dziś bardziej pesymistyczny i przewiduje konflikt. Zapowiedział, że natychmiast włączy się do walki u boku Niemców"4.

27 czerwca 1938 r. Ciano „rozmawiał z Czechosłowakiem Chvalkovskim, któremu powtórzył tę samą radę: porozumienie się z Berlinem”. 19 sierpnia $1938 \mathrm{r}$. strona włoska została poinformowana, że „niemieccy wojskowi uważają, iż w najbliższym czasie - do końca września, akcja militarna w Czechosłowacji jest nieunikniona. Wszystko jest jakoby gotowe w najdrobniejszych szczegółach. Zasadniczą rolę miałoby odegrać lotnictwo. W sferze politycznej niczego jeszcze nie przesądzono. Musimy się więc trzymać tego co ustaliliśmy z [Niemcami] w maju. Zapewniono nas wówczas, że jakiekolwiek odwołanie się do użycia siły jest wykluczone przynajmniej na kilka lat”. 20 sierpnia 1938 r. Ciano polecił ambasadorowi włoskiemu w Berlinie Bernardo Attolico, „aby udał się do Ribbentropa i poprosił go o precyzyjne informacje w kwestii zamierzeń rządu Rzeszy wobec Czechosłowacji, a to w tym celu żebyśmy mogli podjąć kroki mobilizacyjne na naszej zachodniej granicy [tzn. z Francją]. Ta wiadomość odbije się głośnym echem wśród Niemców, ponieważ wyjaśni im, jak daleko gotowi jesteśmy posunąć się. Istotnie wiadomości z Berlina pozwalają przewidywać, że w najbliższym czasie w kwestii czeskiej nastąpi kryzys. Czy uda się ten konflikt ograniczyć do skali lokalnej, czy też Francja podpali prochy? W takim przypadku, nie pozostanie nam nic innego, jak tylko natychmiast stanąć wszystkimi siłami u boku Niemiec. Duce jest gotów do akcji, dlatego musimy wiedzieć - na czas i wszystko - jak sprawy stoją". Ciano uważał, że „Czechosłowacja jest izolowana, a system francuskich przyjaźni - wywrócony”. „Zgodnie z moimi [Ciano] instrukcjami z 20 sierpnia Attolico rozmawiał z Ribbentropem, którego odpowiedź nie jest całkiem jasna. [U Niemców] jest wielka wola działania i wszystko - lub prawie wszystko jest już gotowe, ale wydaje się, że decyzji jeszcze nie podjęto". 17 września 1938 r. Duce oświadczył Ciano, że „podjął decyzję. Jeśli w konflikt zaangażują się Niemcy, Praga, Paryż i Moskwa,

${ }^{4}$ G. Ciano, op. cit., s. 147, 165, 175, 178, 179, 182, 184, 197, 212, 213, 214, 215, 228, 229, 233, 234, 236, 237. 
to ja pozostanę neutralny. Gdyby interweniowała Wielka Brytania nadając konfliktowi wymiar światowy i ideologiczny, wówczas rzucimy się w ogień. Włochy i faszyzm nie mogłyby pozostać neutralne”. 19 września 1938 r. Ciano zauważył, że „wiadomości w sprawie czeskiej są na ogół optymistyczne. Także Duce zaczyna się opowiadać za jej pokojowym rozwiązaniem”. 25 września 1938 r. Ciano odnotował w swoim dzienniku, iż „Hitler uważa też, że Francja i Anglia nie ruszą do [walki]. Gdyby jednak to zrobiły, jest gotów do starcia. Co więcej, zaznacza, że sytuacja militarna Osi jest obecnie tak korzystna, iż może warto byłoby teraz rozegrać tę grę, do której i tak pewnego dnia trzeba będzie nieuniknienie doprowadzić. Duce zapewniał, że gdyby jednak wybuchł ogólny konflikt, my staniemy u boku Niemiec, natychmiast po włączeniu się Anglii do wojny". 25 września 1938 r. Ciano przyznał jednak, że „Duce i ja, choć nie popychaliśmy Niemiec do konfliktu, nie zrobiliśmy też nic, żeby je przed nim powstrzymać". 28 września 1938 r. Duce zatelefonował do Attolica: „Niech pan pójdzie do Führera i powie mu, że uwzględniwszy, iż w każdych okolicznościach będę u jego boku, proponuję opóźnienie rozpoczęcia działań wojennych o 24 godziny. Ten czas rezerwuję sobie na rozważenie, jak ten problem mógłby być rozwiązany". Następnie Ciano pisze, iż poinformował Brytyjczyków o tym, że Duce przyjął prośbę Chamberlaina i zaproponował dwudziestoczterogodzinną zwłokę. Podczas kolejnej audiencji Brytyjczycy przekazali mu posłanie Chamberlaina do Duce oraz kopię dokumentu skierowanego do Hitlera, zawierającego konkretną propozycję konferencji czterech mocarstw, nazwanej później konferencją monachijską ${ }^{5}$.

\section{Czechoslovakia faced with a hostile attitude of Germany and Italy in 1938}

\section{Abstract}

Adolph Hitler's Germany and Benito Mussolini's Italy were both professed enemy of the Czechoslovak state. The Propaganda Minister of the Third Reich Joseph Goebbels did not try to conceal his negative attitude towards Czechoslovakia, similarly to the Italian Foreign Minister Galeazzo Ciano. The diaries of Goebbels and of Ciano shed interesting light on the foreign policy of Germany and Italy. Neither of the authors did try to conceal his aversion to the policy of Czechoslovakia, when analysing a chain of events on the political scene which, in their opinion, confirmed their opinion of the weakness of Prague.

Goebbels paid attention to show trials in Russia and to the policy of Poland towards Lithuania, and declared that nothing was able to save Czechoslovakia. "This state has to disappear - he wrote - the sooner, the better". Ciano, on the other hand, noted Benito Mussolini's remarks, who, after the annexation of Austria into Germany, indicated Czechoslovakia, Switzerland and Belgium as the weak points to be erased from the map of Europe. He stressed that Italy was not interested in the fate of Prague. Highly symbolic was the order given by Ciano to the Italian ambassador in Berlin, Bernardo Attolico, to go to Ribbentrop and ask him about precise information on the plans of the Third Reich towards Czechoslovakia to allow Italy to make preparations for mobilisation so as not to be taken unawares.

\footnotetext{
${ }^{5}$ Ibidem, s. 237.
} 


\section{Чехословакия перед лицом враждебной позиции Германии и Италии в 1938 г.}

\section{Аннотация}

Ярыми врагами чехословацкого государства были Германия Адольфа Гитлера и Италия Бенито Муссолини. Министр пропаганды Третьего Рейха Йозеф Геббельс не таил своего отрицательного отношения к Чехословакии. Подобным образом поступал итальянский министр иностранных дел Галеаццо Чиано. Дневники Геббельса, а также дневники Чиано бросают интересный свет на иностранную политику Германии и Италии. Оба автора не скрывали отвращения к чехословацкой политике, анализируя цепь событий на политической сцене, которые, согласно их мнению, подтверждали тезис о слабости Праги. Геббельс обращал внимание на показательные процессы в России, а также на политику Польши по отношению к Литве и отмечал, что уже ничто не сможет спасти Чехословакию. Это государство должно исчезнуть - писал он - чем скореее тем лучше.

Чиано записал замечания Бенито Муссолини, который после аншлюса Австрии Третим Рейхом, указал, как на сомнительные точки, которые следует удалить с карты Европы - Чехословакию, Швейцарию и Бельгию. Он подчеркивал, что Италия не заинтересована в судьбе Праги. Символическим моментом являлось распоряжение Чиано, отданное итальянскому послу в Берлине Бернардо Аттолико, отправиться к Риббентропу и попросить его о точной информации о намерениях правительства Рейха по отношению к Чехословакии, чтобы предпринять возможные мобилизационные шаги.

\section{Bibliografia}

Ciano G., Dziennik 1937-1943, tł. i oprac. nauk. T. Wituch, Pułtusk 2006

Goebbels J., Dzienniki, t. 1: 1923-1939, wybór, tł. i przypisy E.C. Król, Warszawa 2013

Marek Kazimierz Kamiński, prof. dr hab., pracownik naukowy Instytutu Historii im. Tadeusza Manteuffla PAN; specjalizuje się w historii Polski i najnowszej historii powszechnej oraz historii stosunków międzynarodowych; autor m.in. Kształtowanie się stosunków polsko-czechosłowackich w latach 1948-1960 (Warszawa 2012) oraz Szkice z dziejów Polski i Czechosłowacji w latach trzydziestych XX wieku (Warszawa 2014); były redaktor naczelny „Studiów z Dziejów Rosji i Europy Środkowo-Wschodniej”.

Marek Kazimierz Kamiński, Prof. Dr. hab., he works at the Institute of History of the Polish Academy of Sciences; he specialises in the 20th-century history of Poland and universal history and the history of international relations; he is the author of numerous publications on Polish-Czechoslovak relations and issues, including Developing of Polish-Czechoslovak Relations in 1948-1960 (Warsaw, 2012), and Sketches from the History of Poland and Czechoslovakia in the 1930s (Warsaw, 2014); the former editor-in-chief of the periodical Studies in the History of Russia and Central-Eastern Europe. 